\title{
Myxomatous Aneurysms A Case Report and Literature Review
}

\author{
E. TAMULEVIČIŪTĖ, P. TAESHINEETANAKUL, K. TERBRUGGE, T. KRINGS \\ Division of Neuroradiology, Department of Medical Imaging, Toronto Western Hospital, University of Toronto; Toronto, Canada
}

Key words: atrial myxoma, aneurysm, stroke

Summary

Cardiac myxomas are benign tumors that may lead to neurological manifestations including ischemic stroke, aneurysms or metastases. We describe a patient with multiple intracranial aneurysms who presented with TIA-like symptoms following resection of an atrial myxoma, and review the clinical and imaging features of myxomatous aneurysms as reported in the literature. The most prominent imaging features of myxomatous aneurysms are their multiplicity, fusiform shape and distal location whereas from a clinical point of view they most often present with stroke like symptoms rather than with hemorrhage. These neurological manifestations may occur even after successful and complete surgical removal of the atrial myxoma.

\section{Introduction}

Cardiac myxoma is the most common benign cardiac tumour with an estimated annual incidence of 0.5 per million population ${ }^{1}$. These tumours arise from subendocardial multipotential mesenchymal cells, and may be either solid or papillary; the vast majority (75 $-80 \%)$ are situated in the left atrium ${ }^{2-6}$. There is a $2: 1 \mathrm{fe}-$ male preponderance, and the age at onset is usually between 30 and 60 years ${ }^{2}$. Although atrial myxoma is mostly sporadic, at least $7 \%$ of cases are familial 1,7. The best described familial type is Carney complex, characterized by cutaneous spotty pigmentation, cutaneous and cardiac myxomas, nonmyxomatous extracardiac tumours and endocrinopathies. The classic triad of symptoms from cardiac myxomas is heart failure, constitutional symptoms and em- bolic manifestations ${ }^{8}$. Heart failure occurs in $54 \%-95 \%$ of patients $5,9,10$, constitutional symptoms (myalgia, muscle weakness, arthralgia, fever, weight loss, and fatigue) may occur in up to $90 \%$ of cases 5,9 , while embolic events occur in $10-45 \%$ of patients $5,9-11$. More than two-thirds of myxomatous emboli migrate to the central nervous system $5,12,13$ but any arterial bed may be affected, leading to a large variety of symptoms and signs. The pathology of intracranial manifestations of myxomatous emboli is threefold: cerebral arterial embolism causing ischaemia ${ }^{14,15}$; neoplastic aneurysm formation with or without hemorrhage 14,16 and intraparenchymal metastases ${ }^{14,17}$. Given these different manifestations, neurological symptoms will vary and include neurological deficits, hemorrhages, syncopes, psychiatric symptoms, headaches or epilepsy 18. With rare exceptions, neurological symptoms related to atrial myxomas occur before or at the time of primary tumor diagnosis 19. Reports of delayed neurological symptoms after surgical removal of the myxoma are rare 19-24. Myxomatous aneurysms are classically multiple, fusiform in shape, and located distally on the arterial tree. Aneurysm formation associated with atrial myxoma is caused by myxomatous tumor invasion into the vessel wall ${ }^{25}$. Two major hypotheses of aneurysm formation have been put forward: Stoane et al. ${ }^{26,27}$ postulated that large tumor emboli cause perivascular damage with scarring and that pseudoaneurysm formation follows the obstruction. New et al. ${ }^{26,22}$ hypothesized that the viable tumor emboli penetrate intact or damaged endothelium at the site of final lodgement, with subintimal growth, destruction of the arterial wall, and fibroblastic proliferation. This neoplastic process is accompanied by connective tissue prolifera- 


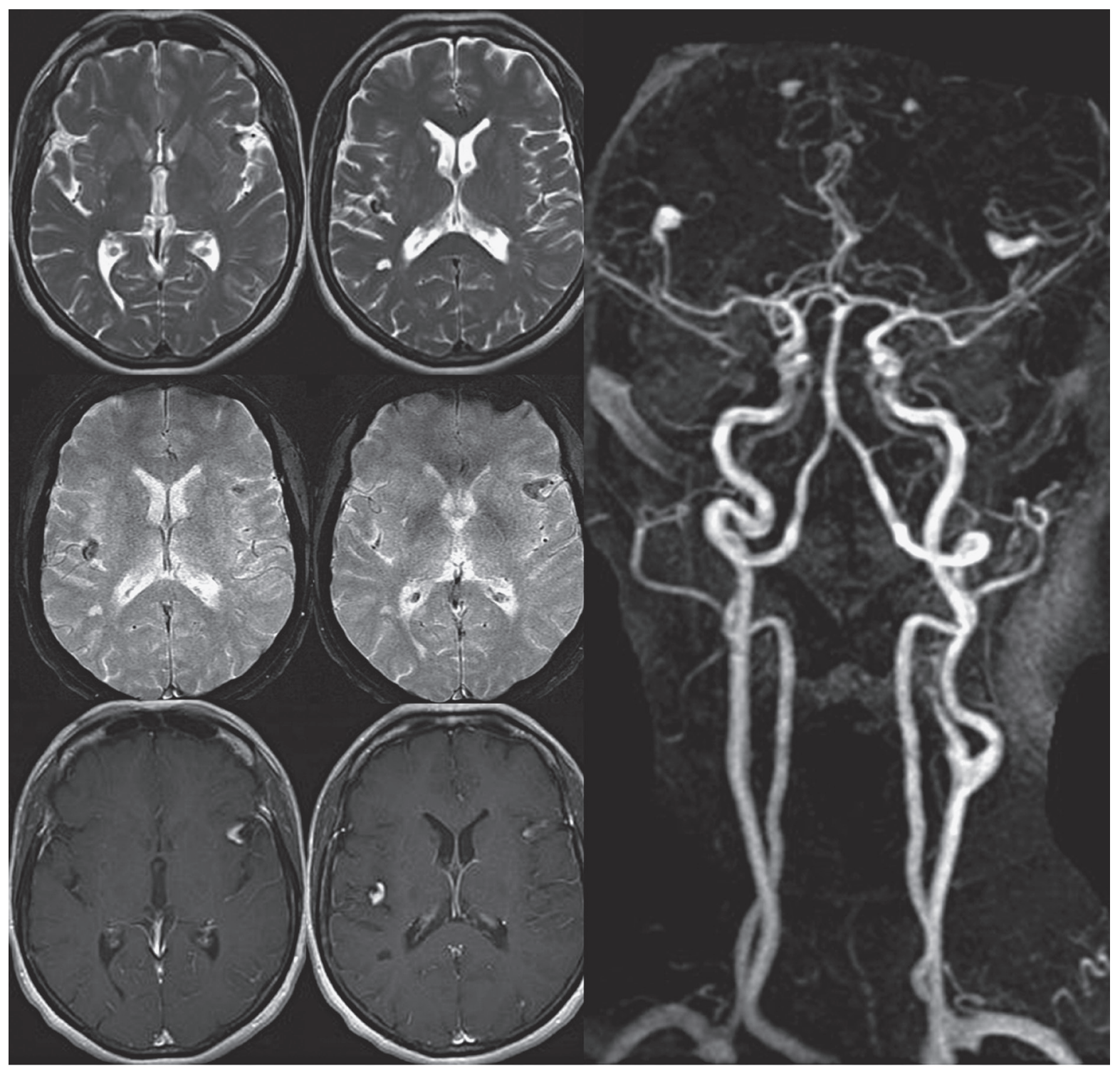

Figure 1 T2,T2 Gradient echo and T1-weighted sequences following contrast administration as well as the contrast enhanced MR angiography demonstrate multiple fusiform outpouchings with contrast enhancement that is most likely related to stagnation or turbulent flow within the aneurysms rather than a calcified or thickened wall. In a nearly symmetrical fashion both M2 and A2 segments are involved. Multiple areas of lacunar remote stroke are seen in the deep white matter.

tion and a mild inflammatory reaction. This can lead to progressive destruction of the wall with displacement of smooth muscle cell by myxomatous tissue. Aneurysm growth can continue even after resection of the cardiac myxoma.

In the literature of the past 20 years, there are approximately 25 case reports on myxomatous aneurysms. However, up to now, these reports did not mention from how many cases of a) aneurysms or b) atrial myxomas the case was recruited. The aim of this present report is to account for this shortcoming by describing the oc- currence rate based on the number of patients with myxomas seen in our university hospital in relation to the number of aneurysms followed by our group and to review the clinical and imaging features of myxomatous aneurysms.

\section{Case Report}

Two separate retrospective databank analyses were performed to identify a) the number of aneurysms managed and b) the number of 
patients seen for atrial myxoma. The latter was derived from the local University Hospital Medical Imaging databank encompassing cases from 1999 to 2010, the former from a dedicated neurovascular databank into which all vascular cases managed between the same period of time were prospectively entered.

During this period of time 40 patients with atrial myxomas and 2246 patients with 3045 aneurysms were seen. A single patient was present in both databases harboring an atrial myxoma and intracranial aneurysms. A retrospective chart analysis of this patient was performed.

The patient had been followed since 1966 when, as a 17-year-old, after a transient episode of weakness in her lower extremities and extensive diagnostic workup an atrial myxoma was identified, surgically removed and proven by histology. In 1978, 12 years after atrial myxoma extirpation the patient experienced a right hemispheric stroke which left her with a moderate left-sided hemiparesis. Cerebral angiography reportedly revealed multiple small and fusiforme distal aneurysms, that were re-assessed and reported to be stable in 1988. The patient became symptomatic again in 2003 when she noted to have occasional episodes of transitory paresthesias in her left upper extremity. These TIA-like symptoms repeated themselves in 2005, and 2006 and ceased after the patient was treated with aspirin.

Neuroimaging revealed stable appearance of a total of six fusiforme distal aneurysms, the sizes of which varied between a few millimeters to $1 \mathrm{~cm}$ incorporating the rolandic and the angular artery on the left, the anterior parietal artery on the right, both distal callosomarginal arteries and the left calcarine artery. The vessel wall of these arteries was slightly thickened and demonstrated a T2 hypointense rim. There was no abnormal blooming artifact on $\mathrm{T} 2$ gradient echo sequences surrounding the aneurysms and therefore no sign for recent or remote hemorrhage in the vicinity of the aneurysms. Following contrast administration, pooling of contrast within the aneurysms was seen suggesting slow flow or recirculation within the aneurysm (Figure 1). Multiple remote areas of ischemia were noted including the lenticulostriate perforator territory on the right, but also the left PICA territory and the deep white matter as well as multiple cortical areas of presumably embolic stroke. Distant from the described aneurysms at the grey-white matter junction of the left parietooccipital transition and the left mid- dle frontal gyrus rounded $2 \mathrm{~mm}$ large susceptibility artefacts were seen suggesting remote intraparenchymal microhemorrhages.

\section{Discussion}

The present literature review was restricted to cases published after 1990 since in addition to the angiographical appearance of myxomatous aneurysms, we also wanted to evaluate MR and CT imaging features. In this period of time 25 cases in 24 reports were described ${ }^{1-2}$, $8,14,16,19,25-26,28-43$. Of those patients, the vast majority $(21=84 \%)$ had multiple aneurysms, whereas in three $(12 \%)$ patients only a single aneurysm was found. The total number of aneurysms in these 25 patients cannot be calculated since for most patients $(n=17)$ the authors only described the occurrence of "multiple" aneurysms without the exact number, in the other cases in between three and four aneurysms were found. Concerning the location of the aneurysms, all but four cases were reported to be present on distal branches. Four aneurysms were located in proximal vessels including the ICA, the proximal M1 segment of the middle cerebral artery, the basilar artery and the P1 segment of the posterior cerebral artery, respectively. The remainder of the aneurysms were located on distal branches (M2 or beyond: $\mathrm{n}=17, \mathrm{~A} 2$ or beyond: $\mathrm{n}=10, \mathrm{P} 2$ or beyond: $n=6)$. The anterior circulation was more commonly affected (18 patients) compared to the posterior circulation (seven patients). Concerning the aneurysm shape, the "classical" berry- type of an aneurysm was only present in one patient, fusiform aneurysms were reported however in 21 patients, the type of aneurysm was not reported in three manuscripts. Clinical presentation of the aneurysm was with stroke in 12, with TIAs in six, with subarachnoid hemorrhage in five patients and with intraparenchymal hemorrhage in two. Two patients each presented with headaches and neurological deficits, one patient presentetd with a syncope. For a detailed description of these results refer to Table 1.

In addition to the described patient, in our databank we have identified 54 adult patients with distal aneurysms. Lesion pathology/etiology was available in 33 patients indicating trauma (seven), infection (three) and dissection 23 as the most common causes. Multiplicity of distal aneurysms, on the other hand was only 
Table 1

\begin{tabular}{|c|c|c|c|c|c|c|c|c|c|c|c|}
\hline Nr. & $\begin{array}{l}\text { Author } \\
\text { Year }\end{array}$ & $\begin{array}{l}\text { Age } \\
\text { Sex }\end{array}$ & H & Presentation & $\begin{array}{c}\text { Aneurysm } \\
\text { finding }\end{array}$ & $\begin{array}{c}\text { Number } \\
\text { of AA }\end{array}$ & Location & Type & Treatment & FU & Outcome \\
\hline 1 & $\begin{array}{l}\text { Ashalatha } \\
2005\end{array}$ & $\begin{array}{l}54 \\
\mathrm{~m}\end{array}$ & - & Stroke, SAH & 6 month & 4 & $\begin{array}{l}\text { distal MCA } \\
\text { and ACA } \\
(\mathrm{A} 3, \mathrm{M} 3)\end{array}$ & Fusiform & $\begin{array}{l}\text { Conservative } \\
\text { (Phenytoin) }\end{array}$ & $\begin{array}{l}6 \\
\text { mo. }\end{array}$ & Seizures \\
\hline 2 & $\begin{array}{l}\text { Walker } \\
2003\end{array}$ & $\begin{array}{c}60 \\
\mathrm{f}\end{array}$ & - & Stroke & 6 years & multiple* & $\begin{array}{l}\text { Right ACA, } \\
\text { MCAs (M4) } \\
\text { SCAs } \\
\text { (proximal) } \\
\text { and PCAs } \\
\text { (P1right and } \\
\text { P2left) }\end{array}$ & Fusiform & $\begin{array}{l}\text { Surgery } \\
\text { (Wrapping) }\end{array}$ & & Stable \\
\hline 3 & $\begin{array}{l}\text { Hwang } \\
2001\end{array}$ & $\begin{array}{l}73 \\
\mathrm{f}\end{array}$ & - & Stroke & 1 year & 4 & $\begin{array}{l}\text { distal MCA } \\
\text { (M3 and M4), } \\
\text { posterior } \\
\text { temporal } \\
\text { branch }\end{array}$ & Fusiform & Conservative & & \\
\hline 5 & $\begin{array}{l}\mathrm{Li} \\
2008\end{array}$ & $\begin{array}{l}27 \\
\mathrm{f}\end{array}$ & - & Stroke & $\begin{array}{l}\text { Index } \\
\text { lesion }\end{array}$ & multiple* & $\begin{array}{l}\text { ICAs (A3, M3 } \\
\text { and M4) and } \\
\text { the proximal } \\
\text { bilateral } \\
\text { posterior } \\
\text { cerebral arteries } \\
\text { (P2's branches), } \\
\text { vertebral artery }\end{array}$ & $\begin{array}{l}\text { Fusiform } \\
\text { and } \\
\text { saccular }\end{array}$ & Conservative & 2 & Stable \\
\hline 6 & $\begin{array}{l}\text { Herbst } \\
2005\end{array}$ & $\begin{array}{l}31 \\
\mathrm{~m}\end{array}$ & - & Stroke & $\begin{array}{l}\text { Index } \\
\text { lesion }\end{array}$ & multiple* & $\begin{array}{l}\text { peripheral } \\
\text { branches of } \\
\text { ACA, MCA, PCA, } \\
\text { vertebrobasilar a. }\end{array}$ & Fusiform & Conservative & 2 & Stable \\
\hline 9 & $\begin{array}{l}\text { O'Rourke } \\
2003\end{array}$ & $\begin{array}{l}48 \\
\mathrm{~m}\end{array}$ & - & Stroke & $\begin{array}{l}\text { Index } \\
\text { lesion }\end{array}$ & multiple* & $\begin{array}{l}\text { anterior (M3, M4) } \\
\text { and posterior } \\
\text { circulation }\end{array}$ & Fusiform & Conservative & $\begin{array}{l}3 \\
\text { mo. }\end{array}$ & $\begin{array}{l}\text { Neurological } \\
\text { defictis. }\end{array}$ \\
\hline 10 & $\begin{array}{l}\text { Eddleman } \\
2010\end{array}$ & $\begin{array}{l}18 \\
\mathrm{~m}\end{array}$ & + & SAH & 4 month & multiple* & $\begin{array}{l}\text { ACA (A3), MCA } \\
\text { (M4) and PCA } \\
(\mathrm{P} 4)\end{array}$ & Fusiform & Conservative & $\begin{array}{l}3 \\
\text { mo. }\end{array}$ & $\begin{array}{l}\text { Aneurysm } \\
\text { enlargment } \\
\text { and new } \\
\text { hemorrhages - } \\
\text { surgery }\end{array}$ \\
\hline 11 & $\begin{array}{l}\text { Roscher } \\
1995\end{array}$ & $\begin{array}{l}? \\
?\end{array}$ & + & Stroke & 2 month & 1 & $\begin{array}{l}\text { Fusiform arterial } \\
\text { aneurysm }\end{array}$ & Fusiform & Conservative & \begin{tabular}{|l}
4 \\
years
\end{tabular} & Stable \\
\hline 12 & $\begin{array}{l}\text { Oguz } \\
2001\end{array}$ & $\begin{array}{l}40 \\
\mathrm{~m}\end{array}$ & - & Stroke & 5 years & multiple* & $\begin{array}{l}\text { bilateral MCA } \\
\text { (M3, M4), left } \\
\text { PCA (P4) }\end{array}$ & Fusiform & Conservative & $\begin{array}{l}12 \\
\text { mo. }\end{array}$ & Stable \\
\hline 13 & $\begin{array}{l}\text { Koo } \\
2009\end{array}$ & $\begin{array}{c}64 \\
\mathrm{f}\end{array}$ & - & TIA & $\begin{array}{l}\text { Index } \\
\text { lesion }\end{array}$ & multiple* & $\begin{array}{l}\text { distal ACA } \\
\text { (A3), MCA } \\
\text { (M3) }\end{array}$ & Fusiform & Conservative & $6 \mathrm{mo}$. & Stable \\
\hline 14 & $\begin{array}{l}\text { Jean } \\
2001\end{array}$ & $\begin{array}{c}32 \\
\mathrm{f}\end{array}$ & + & TIA & 5 years & multiple* & $\begin{array}{l}\text { ACA and MCA } \\
\text { (A3 and M3) }\end{array}$ & Fusiform & Surgery & $\begin{array}{l}4 \\
\text { mo. }\end{array}$ & Stable \\
\hline \multirow[b]{3}{*}{15} & \multirow[b]{3}{*}{$\begin{array}{l}\text { Furuya } \\
1995\end{array}$} & \multirow[b]{3}{*}{$\begin{array}{l}35 \\
\mathrm{~m}\end{array}$} & \multirow[b]{3}{*}{+} & \multirow[b]{3}{*}{ SAH } & \multirow[b]{3}{*}{$\begin{array}{l}\text { Index } \\
\text { lesion }\end{array}$} & \multirow[b]{3}{*}{ multiple* } & \multirow{3}{*}{$\begin{array}{l}\text { ACA (A3), MCA } \\
\text { (M4), PCA (P4) } \\
\text { and distal SCA }\end{array}$} & \multirow[b]{3}{*}{ Fusiform } & Surgery & $\begin{array}{l}4 \\
\text { mo. }\end{array}$ & $\begin{array}{l}\text { New aneuryms } \\
\text { and Seizures }\end{array}$ \\
\hline & & & & & & & & & Conservative & $\begin{array}{l}8 \\
\text { mo. }\end{array}$ & $\begin{array}{l}\text { Seizures, } \\
\text { Angio: stable }\end{array}$ \\
\hline & & & & & & & & & Conservative & $\begin{array}{l}13 \\
\text { mo. }\end{array}$ & Angio: stable \\
\hline
\end{tabular}


Continued ... Table 1

\begin{tabular}{|c|c|c|c|c|c|c|c|c|c|c|c|}
\hline Nr. & $\begin{array}{l}\text { Author } \\
\text { Year }\end{array}$ & $\begin{array}{l}\text { Age } \\
\text { Sex }\end{array}$ & $\mathbf{H}$ & Presentation & $\begin{array}{c}\text { Aneurysm } \\
\text { finding }\end{array}$ & $\begin{array}{c}\text { Number } \\
\text { of } \mathbf{A A}\end{array}$ & Location & Type & Treatment & FU & Outcome \\
\hline \multirow[t]{2}{*}{16} & \multirow[t]{2}{*}{$\begin{array}{l}\text { Nucifora } \\
2001\end{array}$} & $\begin{array}{l}75 \\
\mathrm{f}\end{array}$ & - & Stroke & $\begin{array}{l}\text { Index } \\
\text { lesion }\end{array}$ & multiple* & $\begin{array}{l}\text { posterior right } \\
\text { Sylvian fissure, } \\
\text { left posterior } \\
\text { occipital lobe, } \\
\text { right posterior } \\
\text { parietal lobe } \\
\text { (M3, M4) }\end{array}$ & Fusiform & Conservative & & Stable \\
\hline & & $\begin{array}{l}73 \\
\mathrm{f}\end{array}$ & - & Stroke & $\begin{array}{l}\text { Index } \\
\text { lesion }\end{array}$ & multiple* & $\begin{array}{l}\text { ACA (A3), } \\
\text { MCA bilateral } \\
\text { (M3, M4) }\end{array}$ & Fusiform & Conservative & - & Lost to $\mathrm{F} / \mathrm{U}$ \\
\hline \multirow{3}{*}{17} & \multirow{3}{*}{$\begin{array}{l}\text { Hayashi } \\
1995\end{array}$} & \multirow{3}{*}{$\begin{array}{l}24 \\
\mathrm{~m}\end{array}$} & \multirow{3}{*}{ - } & \multirow{3}{*}{ TIA } & \multirow{3}{*}{$\begin{array}{l}\text { Index } \\
\text { lesion }\end{array}$} & \multirow{3}{*}{3} & \multirow{3}{*}{$\begin{array}{l}\text { distal MCA } \\
\text { (M3 and M4), } \\
\text { proximal left } \\
\text { ICA }\end{array}$} & \multirow{3}{*}{ no detail } & Surgery & 0 & 1 disappeared \\
\hline & & & & & & & & & & ? & $\begin{array}{l}\text { proximal left } \\
\text { cerebral fusiform }\end{array}$ \\
\hline & & & & & & & & & & & $\begin{array}{l}\text { Enlargement, } \\
\text { hemi paresis }\end{array}$ \\
\hline 18 & $\begin{array}{l}\text { Shinn } \\
2009\end{array}$ & $\begin{array}{c}48 \\
\mathrm{f}\end{array}$ & - & Syncope & $\begin{array}{l}\text { Index } \\
\text { lesion }\end{array}$ & multiple* & $\begin{array}{l}\text { ACA, MCA } \\
\text { (A3, M3-4) }\end{array}$ & Fusiform & Conservative & & $\begin{array}{l}\text { Seizure, Sepsis, } \\
\text { Death }\end{array}$ \\
\hline 19 & \begin{tabular}{|l|} 
Katz \\
2008 \\
\end{tabular} & n.a & - & Hemorrhage & n.a. & n.a. & n.a. & Fusiform & n.a. & n.a. & n.a. \\
\hline 20 & $\begin{array}{l}\text { Chen } \\
1993\end{array}$ & $\begin{array}{c}68 \\
\mathrm{f}\end{array}$ & + & $\begin{array}{l}\text { Headaches, } \\
\text { Neurological } \\
\text { Deficit }\end{array}$ & 1 year & multiple* & $\begin{array}{l}\text { ACA and } \\
\text { MCA (A3, } \\
\text { M3-4) }\end{array}$ & $\begin{array}{l}\text { Fusiform } \\
\text { and } \\
\text { saccular }\end{array}$ & Surgery & $\begin{array}{l}2 \\
\text { years }\end{array}$ & $\begin{array}{l}\text { No further } \\
\text { neurological } \\
\text { symptom }\end{array}$ \\
\hline 21 & $\begin{array}{l}\text { Mattle } \\
1995\end{array}$ & $\begin{array}{l}49 \\
\mathrm{~m}\end{array}$ & - & TIA & 3 years & multiple* & $\begin{array}{l}\text { ACA, MCA, } \\
\text { PCA (A3, } \\
\text { M3-4, P3) }\end{array}$ & Fusiform & Conservative & $\begin{array}{l}10 \\
\text { years }\end{array}$ & $\begin{array}{l}\text { Muli-infarct } \\
\text { dementia }\end{array}$ \\
\hline 22 & $\begin{array}{l}\text { Josephson } \\
2005\end{array}$ & $\begin{array}{c}33 \\
\mathrm{f}\end{array}$ & & Stroke & 8 years & multiple* & M3 & Fusiform & Conservative & $\begin{array}{l}\text { year- } \\
\text { ly }\end{array}$ & Asymptomatic \\
\hline 23 & $\begin{array}{l}\text { Yilmaz } \\
2003\end{array}$ & $\begin{array}{c}38 \\
\mathrm{y}\end{array}$ & & $\begin{array}{l}\text { Neurological } \\
\text { Deficit, } \\
\text { Headaches }\end{array}$ & $\begin{array}{l}\text { Index } \\
\text { lesion }\end{array}$ & multiple* & $\begin{array}{l}\text { bilateral ICAs, } \\
\text { M1 giant, } \\
\text { M3-4 and A3 }\end{array}$ & $\begin{array}{l}\text { Saccular } \\
\text { and } \\
\text { Fusiform }\end{array}$ & $\begin{array}{l}\text { Endovascular } \\
\text { treatment with } \\
\text { saccular coiling }\end{array}$ & & $\begin{array}{l}\text { Recurrence and } \\
\text { progression }\end{array}$ \\
\hline \multirow{3}{*}{24} & \multirow{3}{*}{$\begin{array}{l}\text { Iihara } \\
1991\end{array}$} & \multirow{3}{*}{$\begin{array}{c}37 \\
\mathrm{f}\end{array}$} & & \multirow{3}{*}{ TIA } & \multirow{3}{*}{$\begin{array}{l}\text { Index } \\
\text { lesion }\end{array}$} & \multirow{3}{*}{ multiple* } & \multirow{3}{*}{$\begin{array}{l}\text { peripheral } \\
\text { bilateral MCA }\end{array}$} & \multirow{3}{*}{ Fusiform } & \multirow{3}{*}{ Conservative } & $\begin{array}{l}6 \\
\text { mo. }\end{array}$ & $\begin{array}{l}\text { Newly-developed } \\
\text { aneurysms }\end{array}$ \\
\hline & & & & & & & & & & $?$ & $\begin{array}{l}\text { Slight } \\
\text { enlargement }\end{array}$ \\
\hline & & & & & & & & & & $\begin{array}{l}3 \\
\text { years. }\end{array}$ & Stable \\
\hline
\end{tabular}

present in five patients (in addition to the index patient), of those, the etiology could be identified in two patients (infectious aneurysms), while in the remaining three patients the etiology remained unknown (negative CT of the chest, negative blood cultures, no history of trauma). Fusiform distal aneurysms were found in 21 of the 54 patients. This review of our aneurysm databank indicates that, although myxomatous aneurysms are exceedingly rare, they have to be included in the differential diagnoses in those patients with multiple distal aneurysms or with distal fusiform aneurysms. It is also important to emphasize that the only patient identified in our databank with distal AND multiple AND fusiform aneurysms was the reported index patient with myxomatous aneurysms indicating that these aneurysms have rather characteristic imaging features which should enable their identification. Our findings are in keeping with the literature where distal location, fusiform shape and multiplicity was present as the typical imaging features of myxomatous aneurysms. A chart review of all patients at our institution who presented with atrial myxoma revealed neurological complications in nine of the 40 identified patients, including metas in one patient, and stroke or TIAs in eight patients (of whom one patient was the index patient) which is in keeping with the literature as described in the introduction.

Concerning treatment, it is important to notice that the aneurysms may continue to grow despite surgical removal of the myxoma 35,43 . Patients presenting with hemorrhage are generally considered surgical candidates given their distal location, however, since preservation of the vessel is rarely possible, endovascular parent vessel occlusion may also be per- 
formed in cases presenting with hemorrhage. If their finding is incidental or if they present with stroke, treatment is not advised given the high risk of neurological deficits.

Three major problems have to be mentioned concerning the present case description, one being the referral bias as a university hospital, the second being, that a single case does not enable us to give true values of incidence and prevalence of myxomatous aneurysms, the third being that cerebral involvement may be underesti- mated since routinely, imaging of the CNS is not routinely performed in patients with atrial myxoma without neurological deficits and is in our practice only suggested for symptomatic patients. Still, we think that this report and the review of the literature underlines, that in cases with yet undiagnosed atrial myxoma, the clinician has to think about the entity of myxomatous aneurysms in the setting of multiple, fusiform or distally located cerebral aneurysms and should consider cardiac imaging.

\section{References}

1 O'Rourke F, Dean N, Mouradian MS, et al. Atrial myxoma as a cause of stroke: case report and discussion. Can Med Asso J. 2003; 169: 1049-1051.

2 Eddleman CS, Gottardi-Littell NR, Bendok BR, et al. Rupture of cerebral myxomatous aneurysm months after resection of the primary cardiac tumor. Neurocrit Care. 2010; 3 .

3 Swartz MF, Lutz CJ, Chandan VS, et al. Atrial myxomas: pathologic types, tumor location, and presenting symptoms. J Card Surg. 2006; 21: 435-440.

4 Yu K, Liu Y, Wang H, et al. Epidemiological and pathological characteristics of cardiac tumors: a clinical study of 242 cases. Interact Cardiovasc Thorac Surg. 2007; 6: 636-639.

5 Pinede L, Duhaut P, Loire R. Clinical presentation of left atrial myxoma. A series of 112 consecutive cases. Medicine (Baltimore). 2001; 80 (3): 159-172.

6 Hart RG, Albers GW, Koudstaal PJ. Cardioembolic stroke. In: Ginsberg MD, Bogousslavsky J, editors. Cerebrovascular disease: pathophysiology, diagnosis and management. London: Blackwell Science; 1998; 1392-1429.

7 McCarthy PM, Piehler JM, Schaff HV, et al. The significance of multiple, recurrent and "complex" cardiac myxomas. J Thorac Cardiovasc Surg. 1986; 91 (3): 389-396.

8 Nucifora PGP, Dillon WP. MR diagnosis of myxomatous aneurysms: report of two cases. Am J Neuroradiol. 2001; 22: 1349-1352.

9 Markel ML, Waller BF, Armstrong WF. Cardiac myxoma: A review. Medicine (Baltimore). 1987; 66: 114-125.

10 St John Sutton MG, Mercier LA, Giuliani ER, et al. Atrial myxomas. A review of clinical experience in 40 patients. Mayo Clin Proc. 1980; 55: 371-376.

11 Blondeau P. Primary cardiac tumours. French studies of 533 cases. Thorac Cardiovasc Surg. 1990; 38: 192-195.

12 Knapper LE, Biller J, Adams HP, et al. Neurologic manifestations of atrial myxoma. A 12-year experience and review. Stroke. 1988; 19: 1435-1440.

13 Sandok BA, Von Estorff I, Giuliani ER. CNS embolism due to atrial myxoma: Clinical features and diagnosis. Arch Neurol. 1980; 37: 485-488.

14 Rodriguez FJ, Brown RD, Mohr JP, et al. Embolic atria myxoma with neoplastic aneurysm formation and haemorrhage: a diagnostic challenge. Neuropathol Appl Neurobiol. 2006; 32: 213-216.

15 Roeltgen DP, Weimer GR, Patterson LF. Delayed neurologic complications of left atrial myxoma. Neurology. 1981; 31: 8-13

16 Chen HJ, Liou CW, Chen L. Metastatic atrial myxoma presenting as intracranial aneurysms with hemorrhage: case report. Surg Neurol. 1993; 40: 61-64.

17 Budzilovich G, Aleksic S, Greco A, et al. Malignant cardiac myxoma with cerebral metastases. Surg Neurol. 1979; 11: 461-469.

18 de Almeida LA, Hueb JC, de Moraes Silva MA, et al. Cerebral ischemia as initial neurological manifestation of atrial myxoma: Case report. Arq Neuropsiquiatr. 2006; 64 (3-A): 660-663.

19 Jean WC, Walski-Easton SM, Nussbaum ES. Multiple intracranial aneurysms as delayed complications of an atrial myxoma: case report. Neurosurgery. 2001; 49: 200-202; discussion 202-203.

20 Chen HJ, Liou CW, Chen L: Metastatic atrial myxoma presenting as intracranial aneurysms with hemorrhage: Case report. Surg Neurol. 1993; 40: 61-64.

21 Desousa AL, Muller J, Campbell RL, et al. Atrial myxoma: A review of the neurological complications, metastases, and recurrence. J Neurol Neurosurg Psychiatry. 1978; 41: 1119-1124.

22 New PFJ, Price DL, Carter B. Cerebral angiography in cardiac myxoma. Radiology. 1970; 96: 335-345.

23 Roeltgen DP, Weimer GR, Patterson LF. Delayed neurologic complications of left atrial myxoma. Neurology. 1981; 31: 8-13

24 Sandok BA, von Estorff I, Giuliani ER. Subsequent neurological events in patients with atrial myxoma. Ann Neurol. 1980; 8: 305-307.

25 Lee VH, Connolly HM, Brown RD Jr. Central nervous system manifestations of cardiac myxoma. Arch Neurol. 2007; 64 (8): 1115-1120.

26 Furuya K, Sasaki T, Yoshimoto Y, et al. Histologically verified cerebral aneurysm formation secondary to embolism from cardiac myxoma case report. J Neurosurg. 1995; 83: 170-173

27 Stoane L, Allen JH Jr, Collins HA. Radiologic observations in cerebral embolization from left heart myxomas. Radiology. 1966; 87: 262-266.

28 Ashalatha R, Moosa A, Gupta AK, et al. Cerebral aneurysms in atrial myxoma: a delayed, rare manifestation. Neurol India. 2005; 53 (2): 216-218.

29 Walker MT, Kilani RK, Toye LR, et al. Central and peripheral fusiform aneurysms six years after left atrial myxoma resection. J Neurol Neurosurg Psychiatry. 2003; 74: 281-282.

30 Hwang BJ, Lev MH. Distinctive MR Imaging appearance of hemorrhagic cerebral aneurysms associated with atrial myxoma. Am J Roentgenol. 2001; 177: 925-927. 
31 Li Q, Shang H, Zhou D, et al. Repeated embolism and multiple aneurysms: central nervous system manifestations of cardiac myxoma. Eur J Neurol. 2008; 15: 112113.

32 Herbst M, Wattjes MP, Urbach H, et al. Cerebral embolism from left atrial myxoma leading to cerebral and retinal aneurysms: a case report. Am J Neuroradiol. 2005; 26: 666-669.

33 Sabolek M, Bachus-Banaschak K, Bachus R, et al. Multiple cerebral aneurysms as delayed complication of left cardiac myxoma: a case report and review. Acta Neurol Scand. 2005: 111: 345-350.

34 Roscher AA, Kato NS, Quan H, et al. Intra-atrial myxomas, clinical-pathologic correlation based on two case studies including historical review. J Cardiovasc Surg (Torino). 199637 (6 Suppl 1): 131-137. Review.

35 Oguz KK, Firat MM, Cila A. Fusiform aneurysms detected 5 years after removal of an atrial myxoma Neuroradiology. 2001; 43 (11): 990-992.

36 Koo YH, Kim TG, Kim,OJ, et al. Multiple fusiform cerebral aneurysms and highly elevated serum interleukin-6 in cardiac myxoma. J Korean Neurosurg. 2009; Soc 45: 394-396.

37 Hayashi S, Takahashi H, Shimura T, et al. A case of multiple cerebral aneurysm which showed rapid growth caused by left atrial myxoma. No Shinkei Geka. 1995; 23 (11): 977-980.

38 Shinn SH, Chon SH, Kim HJ. Multiple cerebral aneurysms associated with cardiac myxoma in a patient with chronic renal failure: how can we resolve multiple cerebral aneurysms? Thorac Cardiovasc Surg. 2009; 57 (1): 47-48.
39 Katz MG, Finkelshtein V, Raichman DBA, et al. Surgical resection of left atrial myxoma presenting with acute multiple hemorrhagic cerebral infarctions: a case report. Heart Surg Forum. 2008; 11 (3): 169-171.

40 Mattle HP, Maurer D, Sturzenegger M, et al. Cardiac myxomas: a long term study. J Neurol. 1995; 242 (10): 689-694.

41 Josephson SA, Johnston SC. Multiple stable fusiform intracranial aneurysms following atrial myxoma. Neurology. 2005; 64 (3): 526.

42 Yilmaz MB, Akin Y, Güray U, et al. Late recurrence of left atrial myxoma with multiple intracranial aneurysms. Int J Cardiol. 2003; 87 (2-3): 303-305.

43 Iihara K, Kikuchi H, Nagata I. Left atrial myxoma with cerebral oncotic aneurysms with special reference to the importance of serial angiography. No Shinkei Geka. 1991; 19 (9): 857-860.

T. Krings, $\mathrm{MD}, \mathrm{PhD}$

University of Toronto

Toronto Western Hospital, UHN

Division of Neuroradiology

399 Bathurst St., 3MCL - 429

Toronto, ON, M5T 2S8, Canada

Tel.: 001 416-603-5562

Fax: 001 416-603-4257

E-mail: timo.krings@uhn.on.ca 